\title{
An Investigation of the Geometric Thinking Levels of Middle School Mathematics Preservice Teachers According to SOLO Taxonomy: "Social Distance Problems"
}

\author{
Mehmet İhsan YURTYAPAN* \\ Bursa Uludăg University, Institute of Education Sciences, Bursa, Turkey \\ ORCID: 0000-0001-9788-7725
}

\author{
Gül KALELİ YILMAZ \\ Bursa Uludăg University, Faculty of Education, Department of Mathematics and Science, \\ Bursa, Turkey \\ ORCID: 0000-0002-8567-3639
}

\begin{tabular}{l}
\hline \hline Article history \\
\hline Received: \\
06.12 .2020
\end{tabular}

Received in revised form: 11.01.2021

Accepted:

02.02.2021

Key words:

Covid-19,

Geometric thinking,

Preservice teachers,

Social distance,

Solo taxonomy

\begin{abstract}
The aim of this study is to examine the geometric thinking levels of middle school mathematics preservice teachers regarding the problem situations regarding the concept of social distance according to the SOLO taxonomy. The research was conducted using the special case method, one of the qualitative research methods. The working group, studying at a state university in Turkey in middle school mathematics teaching department consists of 80 preservice teachers. While determining the participants, purposeful sampling method was used because the preservice teachers who took "Basics of Mathematics II" and "Special Teaching Methods II" courses were selected. In the study, semistructured interviews were conducted with 15 preservice teachers since it was aimed to examine remarkable situations from the answers given to open-ended questions. Descriptive analysis technique was used while analyzing the data. Most of the answers given in the study were found to be below the relational geometric thinking level. As a result, it was determined that most of the answers given reflected quantitative learning. In line with this result obtained in the study, it is suggested that openended questions about life should be included frequently in teaching in order to reach the relational and extended abstract level answers that reflect qualitative learning.
\end{abstract}

\section{Introduction}

Human nature wants to know, because man was born with the desire to know. For this reason, he tries to understand, explore, and learn by constantly being curious about the elements surrounding him (Aristotales, 1993). For this, he uses visual actions such as measuring and comparing. At the same time, the effort to be aesthetic in the works built by human beings supports these actions. It can be said that this accumulation obtained in the process systematized and caused the formation of the geometry field. Geometry is a visualized field of mathematics, which is derived from the combination of "Geo" (place) and 
"metric" (measurement). Therefore, understanding, classifying, and knowing the properties of geometric concepts and shapes in detail contributes to the solutions of mathematical problems (National Council of Teachers of Mathematics [NCTM], 2000). In addition, it can be said that geometry and geometric thinking skills are used in many scientific (engineering, physics) and artistic (architecture, handicrafts) fields (Olkun, 2003; Tekin, 2007).

Geometric thinking indeed plays a critical role in the mathematics curriculum as it provides students with the opportunity to build an inferential structure by combining their knowledge of mathematics with real-life situations (Hvizdo, 1992). For this purpose, geometry subjects are frequently included in primary and secondary education mathematics curriculum in Turkey (Ministry of National Education [MoNE], 2018). Thus, the development of geometric thinking and academic success are aimed (MoNE, 2009a, 2009b, 2013). Despite this being the target, it has been concluded in some studies that students' geometric thinking levels are not at the desired level. (Bulut, Öner-Sünkür, Oral, \& İlhan, 2012; Fidan \& Türnüklü, 2010; Halat, 2006; Kaleli-Yılmaz \& Koparan, 2016; Olkun \& Toluk, 2007). Teachers have a great responsibility at this point in order to change the current situation of students. Because in order for the teaching to be realized at the expected level, the teacher must have detailed knowledge about his field (Fennema \& Loef, 1992; Kahan, Cooper, \& Bethea, 2003). According to research, teachers' knowledge of mathematics also affects the decisions they make in learning environments (Fennema \& Loef, 1992; Lloyd \& Wilson, 1998; Van Dooren, Verschaffel, \& Onghena, 2002). Therefore, it is important for teachers to question their own learning and be aware of what they know or not (Shulman, 1986). It is thought that it will be useful to conduct studies that determine the geometric thinking levels of teachers while they are candidates in creating this awareness.

When literature is examined, studies on geometric thinking or understanding are frequently encountered and Van Hiele geometric comprehension levels are generally used in these studies (Duatepe, 2004; Gökbulut, Sidekli, \&Yangın, 2010; Halat, 2006; Kılıç, 2003; Usiskin, 1982; Van Hiele, 1986; Yi, Flores, \& Wang, 2020). In some studies, it is seen that the Structure of the Observed Learning Outcome [SOLO] taxonomy, which is very similar to Van Hiele's geometric thinking levels, is also preferred as an alternative (Göktepe, 2013; Konyalıhatipoğlu, 2016; Köse, 2018). The SOLO taxonomy was developed by Biggs and Collis (1982) as a model to evaluate the structure of observable learning outcomes. In this model, the evaluation is made according to the quality and structure of the answers given by the students to the questions. The answers given are analyzed with certain criteria and SOLO Taxonomy is used as an effective tool in determining the learning level of the concepts (Akbaş-Ertem, 2016; Groth \& Bergner, 2006).

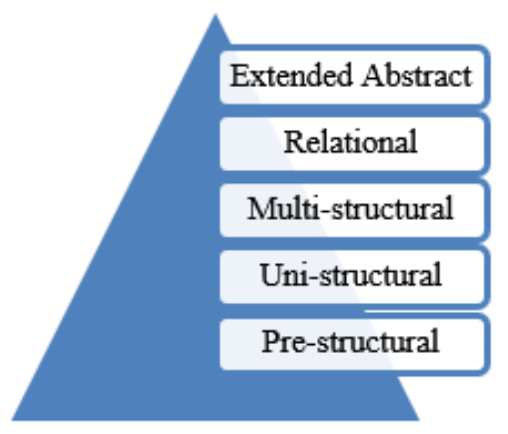

Figure 1. Hierarchical Structure of the SOLO Taxonomy (Çetin \& İlhan, 2016, p.862) 
Since the SOLO taxonomy has a hierarchical integrity, each level includes the skills acquired at previous levels (Tomperi, 2016). The levels in Figure 1 show that student responses can be evaluated in five different ways (Callingham, 1999). As you move up the pyramid, consistency, unity, and versatile evaluations increase (İlhan, 2015). Taxonomy examines students' answers at five levels. These are: "Pre-structural", "Uni-structural", "Multistructural", "Relational" and "Extended Abstract". There is almost no relationship between the question and student answer at the pre-structural level (Brabrand \& Dahl, 2009). At unistructural level, the student focuses on only one aspect of the problem and cannot produce an idea about its place in the whole (Groth \& Bergner, 2006). At the level of multi-structural, the student evaluates the question from more than one point but cannot establish a connection between them (Padiotis \& Mikropoulos, 2010). At the level of the Relational structural, the student focuses on more than one point in his answer and can explain the relationship between them (Weyers, 2006). At the extended abstract level, which is the last level of the SOLO taxonomy, the student establishes connections beyond the existing information (Çetin \& Ilhan, 2016). Actions such as establishing a theory, making generalizations, predicting, creating a hypothesis or combining their knowledge and applying them to a new field are behaviors that show that the student is at the (desired) level (Barbrand \& Dahl, 2009). SOLO taxonomy allows in-depth analysis of the situation due to its flexible nature. Unlike the Van Hiele geometric thinking model, which is frequently preferred in studies on geometric thinking, it does not aim to refer to the general stage of the individual. Instead of classifying students, taxonomy aims to classify the levels of their answers according to the current situation. Because, cognitively, the level of the person may vary from day to day (Çelik, 2007). For this reason, the SOLO model focuses on the answers given by individuals rather than detecting their cognitive level. Therefore, the feature that makes this model different is that it examines the thinking processes used by the individual to reach the answer together with the answer given to the problem situation (Biggs \& Collis, 1991; Pegg \& Tall, 2001).

When the literature is examined, it is seen that the studies on geometry using the SOLO taxonomy are related to spatial (Göktepe, 2013; Göktepe \& Özdemir, 2013; Köse, 2018; Özdemir \& Göktepe-Yıldız, 2015) or two-dimensional plane (Konyalıhatipoğlu, 2016). However, in the literature review, it was observed that there was no study investigating the geometric thinking levels of preservice teachers regarding real-life problem situations. In this context, in these days when we are experiencing the coronavirus epidemic; the concept of "social distance", which reduces the spread of the virus, saves lives and has an important place in our lives, comes to the fore. "Social distance" refers to the physical distance of 1.5-2 meters between individuals in order to prevent the virus from spreading in social areas (Turkey Republic Health Ministry [TRHM], 2020). In order for people to maintain social distancing in public areas, each individual should act in a certain settlement order. Geometry information must be used to provide this layout. In order to prevent the disease from being transmitted, in many places in our daily life such as banks, hospitals, markets, settlements suitable for social distance were made, waiting points and some warning signs reminding the social distance rule were created. However, there are no predetermined waiting points or warning signs showing the layout in all social areas. In addition, it is observed that warning signs showing the settlement order by some institutions are incorrect (Mekouar, 2020). Therefore, in order for people to obey this vital rule everywhere, they should question their distance from the people around them and be able to guess where their position should be in order to settle in any area properly. For this reason, it is thought that the ability of every individual in the society to solve such real problem situations that they encounter in their daily life regarding the concept of social distance depends on geometric thinking skills. In this study, the problem situations that can be encountered in real life are presented based on the 
concept of "social distance" in order to determine the geometric thinking levels of the mathematic preservice teachers who have an important place in the upbringing of future generations. In addition, since there is a geometric layout in the social distance problem situations presented in the study, it can be said that this aspect of the study is also related to the construction of geometric shapes. The purpose of geometric construction studies is to find a solution to a geometric problem instead of obtaining certain shapes by applying a standard procedure with a compass or a unitless ruler (Erduran \& Yeşildere, 2010; Napitupulu, 2001). Therefore, the social distance problem situations we experienced during the coronavirus epidemic process were used to examine the geometric thinking levels of preservice teachers, as they include elements for the construction of geometric concepts and geometric shapes. In addition, for the reasons stated above, it is thought that the SOLO taxonomy offers important opportunities to examine the geometric thoughts of pre-service teachers regarding the social distance problem situations that are the subject of the study. In light of all this information, the main purpose of the study is to examine the geometric thinking levels of middle school mathematics preservice teachers about the concept of "social distance" related to life according to the SOLO model.

\section{Problem Statement}

According to the SOLO taxonomy, what are the geometric thinking levels of middle school mathematics preservice teachers for social distance problem situations?

\section{Method}

\section{Research Model}

This study was conducted with a case study, one of the qualitative research methods. The qualitative research method focuses on the experiences of the individuals researched (Strauss \& Corbin, 1998). It allows the researcher to observe the investigated situation in its own flow, to determine and evaluate the meanings that the participants have constructed in the mind of the subject (Denzin \& Lincoln, 1998). In this context, the case study has the features provided by qualitative research methods. In addition, it has been widely preferred in educational research for many years. Because the special case method is preferred in understanding various issues of education, especially when the "How?" and "Why?" questions are needed to be answered (Yin, 1984). Case studies aim to examine the subject in depth. Therefore, the number of participants should be small. In addition, different research methods and many data collection tools can be used in case studies. This situation provides a detailed research opportunity about the working group and sample cases can be examined in their nature. In this context, the case study method was used since the geometric thinking levels of the preservice teachers about the related to life of "social distance" were examined in depth with data collection tools (document analysis, interview) with a small number of participants.

\section{Study Group}

The working group of the research consists of 80 middle school mathematics preservice teachers who study at a state university in the west of Turkey. In this study, the sample was determined by purposeful sampling method. According to Patton (1987), purposeful sampling in qualitative research allows for in-depth examination of special cases containing rich information in the target of the research (as cited in Y1ldırım \& Şimşek, 2016, p.118). For this reason, the participants in the study were determined from the first and third grade middle school mathematics preservice teachers who have seen the "Basics of 
Mathematics II" and "Special Teaching Methods II" courses in line with the purpose of the study. Within the scope of these lessons, the preservice teachers learned the basic geometry subjects (basic geometric concepts and drawings, triangles and quadrilaterals, length, area measurement, and others) in the middle school mathematics course. Since the aim of the study was to reach as many preservice teachers as possible and to identify special cases containing rich data, two open-ended questions on the concept of "social distance" were directed to 80 middle school preservice mathematic teachers in the first stage of the study. Geometric thinking levels were determined by analyzing the answers obtained from 80 middle school preservice teachers according to the SOLO taxonomy. The preservice teachers in the study group were coded as $\mathrm{PS}_{1}, \mathrm{PS}_{2}, \mathrm{PS}_{3} \ldots$ In the second stage of the study, semi-structured interviews were conducted with 15 middle school preservice teachers in order to examine the special cases containing rich information in depth. While determining the preservice teachers to be interviewed in a semi-structured manner, equal number of preservice teachers from each geometric thinking level could not be selected. Because it has been observed that there are too many answers in some levels of geometric thinking, and no answers at some levels. Therefore, the participants to be interviewed in a semi-structured way were determined as two or three people from each geometric thinking level, as much as possible, and the information about preservice teachers (personal characteristics, communication skills, and so on) received from the lecturer. 25-30-minute semi-structured interviews were conducted with a total of 15 middle school mathematic preservice teachers in line with the voluntary principle. Since the subject of "social distance" is related to the coronavirus, which deeply affects the society, while determining the study group, due to the possibility that the relatives of the preservice teachers may be sick or have passed away from from Covid-19, we tried to be extremely sensitive all throughout. . According to Yıldırım and Şimşek (2016), purposeful sampling is a method that enables the discovery and explanation of facts and events in many cases. For this reason, the sample of the research was created by purposeful sampling method.

\section{Data Collection Tools}

The data were obtained from open-ended questions asked to preservice teachers, semistructured interviews for these questions and document analysis. According to Türnüklü (2000), open-ended questions posed in the interview allow interviewers to learn in a more detailed fashion and inquire into the accurate reasons for interviewees' behaviour, opinions and feelings pertaining to any subject. In semi-structured interviews, there is an interview form consisting of open-ended questions prepared beforehand in accordance with the purpose of the research. In addition, in such interviews, additional questions may be asked to preprepared questions, depending on the answers given by the interviewees. Semi-structured interviews make up a suitable research technique for educational research as they help the researcher to obtain more detailed information about the problem situation (Türnüklü, 2000).

The interview form prepared by the researcher to examine the geometric thinking levels towards the concept of "social distance" consists of two open-ended questions and semistructured interview questions related to these questions. There is a geometric settlement in the problem situations in the open-ended questions prepared for the concept of "social distance". Therefore, the problem cases are directed to the construction of basic geometric shapes (triangle angle-side relationship, relationship between triangle side lengths, and alike.). In the study conducted by Şengün (2017) to examine the processes of middle school students' construction of triangles in a paper-pencil and dynamic geometry environment, it was observed that students in the paper-pencil environment could not explain the relationship between the triangle angle-edge relationship, the side lengths in the triangle, and they drew 
triangles that were impossible to draw. The "social distance" problem situations prepared in this study were prepared by examining the situations underlying the mistakes made while constructing the triangle identified in the literature. The reason why problem situations are created by examining geometric construction studies is that geometric construction studies allow to examine all the features of the constructed building (Cherowitzo, 2006). Since this situation is compatible with the purpose of the study in order to examine the geometric thinking levels for social distance problem situations in depth, this way was followed in the preparation of social distance problem situations. Expert opinion was consulted to ensure the content validity of the questions. While preparing the interview questions, the pilot study was conducted with 10 preservice teachers. As a result of the pilot study, the transpose and long sentence structures that were in the first problem situation were corrected. In the second problem case, corrections were made for the visual in the question. In this way, it was ensured that the questions were made more understandable serving the purpose. Teachers participating in the pilot study were not included in the main study. The interviews were conducted individually on a voluntary basis. Semi-structured interviews were conducted with a total of 15 preservice teachers by determining two or three preservice teachers from each level. Due to the pandemic, interviews were carried out individually for 25-30 minutes using video conference method. Audio recording was made with the permission of the participants.

\section{Data Analysis}

In this study, semi-structured interviews conducted within the scope of the answers to open-ended questions that were then transformed into written texts. Later, descriptive analysis technique was applied in order to examine geometric thinking levels within the framework of SOLO taxonomy. In the descriptive analysis technique, data are summarized and interpreted according to previously determined themes. In addition, this technique aims to reflect the opinions of the individuals in a striking way by directly quoting the answers given by the participants (Yıldırım \& Şimşek, 2016). During the descriptive analysis, the answers given by the preservice teachers to the questions were examined and the criteria of the levels were determined according to the SOLO taxonomy. In this context, the criteria sought in the answers of the preservice teachers and the levels of the answers are given in Table 1.

Table 1. The geometric thinking criteria sought in the answers given by the preservice teachers to the questions according to their solo taxonomy levels.

\begin{tabular}{|c|c|c|}
\hline Thinking Levels & Criteria for Question 1. & Criteria for Question 2. \\
\hline Pre-structural & $\begin{array}{l}\text { It approaches the problem situation only as } \\
\text { shape. This situation can be in two ways: } \\
\text { 1) Their visual explanations are only verbal } \\
\text { and no draft drawing has been made. } \\
\text { 2) The draft has been drawn. But there are no } \\
\text { geometric explanations about how the drawing } \\
\text { was created. }\end{array}$ & $\begin{array}{l}\text { Geometric descriptions are not made. It is } \\
\text { only approached formally. For example, } \\
\text { the signboard should be illuminated, } \\
\text { written in large... etc. }\end{array}$ \\
\hline Uni-structural & $\begin{array}{l}\text { The problem situation is approached from a } \\
\text { single point of view with geometric thinking. } \\
\text { For example, by drawing a single row, it } \\
\text { focuses only on the distance between people } \\
\text { in front and behind. It does not consider the } \\
\text { shape as a whole. }\end{array}$ & $\begin{array}{l}\text { Geometric explanations are considered } \\
\text { one-dimensional. The shape is not } \\
\text { considered holistic. }\end{array}$ \\
\hline Multi -structural & $\begin{array}{l}\text { The problem situation is approached with } \\
\text { multi-dimensional geometric thinking. } \\
\text { However, the solution is incomplete or } \\
\text { incorrect. For example, the maximum number } \\
\text { of people is ignored or operational error is }\end{array}$ & $\begin{array}{l}\text { Considering that the shape on the } \\
\text { signboard is wrong, the shape is evaluated } \\
\text { holistically. Explanations made are } \\
\text { supported by correct expressions with } \\
\text { geometry content. However, no }\end{array}$ \\
\hline
\end{tabular}


Relational

Extended Abstract made in the calculations.

Correct geometric explanations are made for the problem situation. An accurate drawing is made considering the maximum number of people.

Correct geometric explanations are made for the problem situation. An accurate drawing is made considering the maximum number of people. In addition, drawing made by going beyond the question is associated with elements of everyday life. In other words, the argument created is supported by real life elements. For example, Bee honeycomb. suggestions are made about the signboard. The explanations made are supported with verbal and visual expressions containing geometry. Suggestions are made about the signboard.

The shape is evaluated geometrically from multiple points of view. The geometric explanations are made as verbal and visual. Corrections are made about the signboard. It goes beyond the question and makes multiple different suggestions for the signboard. Like showing more than 4 people.

In the analysis of the data, the double-coding procedure developed by Miles and Huberman (1994) was used for coding reliability. The researchers completed the rating process by using the scale. In this study, inter-researcher reliability was calculated as $87 \%$. Consensus was reached on all codes. According to Miles and Huberman (1994), if the coding is $70 \%$ and above, the coding is reliable. As a result, it has been determined that the designed scale is suitable for measuring the levels of the SOLO Taxonomy consistently and reliably.

\section{Findings and Comments}

In this section, the findings and comments related to the geometric thinking levels of the preservice teachers according to the SOLO taxonomy regarding the problem situations with social distance content are included.

\section{Findings and Comments in Question 1}

The $1^{\text {st }}$ question about "Social Distance" that preservice teachers are asked to answer is given below.

"Experts stated that the social distancing between people should be at least two meters due to the Covid 19 outbreak. Ahmet, your relative who is interested in the food business, does not know how to determine the waiting points suitable for social distance in order to manage the crowd in the waiting area in front of the workplace. Knowing that you are a preservice math teacher, Ahmet asks you to create the waiting points in accordance with the social distance rule that will have maximum customers in the waiting area together with the draft drawing indicating the distance between them. How would you help Ahmet? Explain in detail."

The geometric thinking levels according to the SOLO taxonomy of the answers given by the preservice teachers for the $1^{\text {st }}$ question are shown in Table 2.

Table 2. Analysis of preservice teachers' answers to the $1^{\text {st }}$ question according to the SOLO taxonomy.

\begin{tabular}{lll}
\hline Thinking Levels & Preservice Teachers & $\begin{array}{l}\text { Number } \\
\text { Participants }\end{array}$ \\
\hline Pre-structural & $\mathrm{PS}_{10}, \mathrm{PS}_{14}, \mathrm{PS}_{20}, \mathrm{PS}_{27}, \mathrm{PS}_{59}, \mathrm{PS}_{65}$ & $6(\% 7,5)$ \\
Uni-structural & $\mathrm{PS}_{1}, \mathrm{PS}_{2}, \mathrm{PS}_{4}, \mathrm{PS}_{8}, \mathrm{PS}_{12}, \mathrm{PS}_{36}, \mathrm{PS}_{57}, \mathrm{PS}_{70}$ & $8(\% 10)$ \\
Multi-structural & $\mathrm{PS}_{5}, \mathrm{PS}_{6}, \mathrm{PS}_{7}, \mathrm{PS}_{11}, \mathrm{PS}_{13}, \mathrm{PS}_{15}, \mathrm{PS}_{16}, \mathrm{PS}_{17}, \mathrm{PS}_{18}, \mathrm{PS}_{19}$, & $37(\% 46,25)$ \\
& $\mathrm{PS}_{21}, \mathrm{PS}_{25}, \mathrm{PS}_{29}, \mathrm{PS}_{30}, \mathrm{PS}_{31}, \mathrm{PS}_{37}, \mathrm{PS}_{39}, \mathrm{PS}_{40}, \mathrm{PS}_{41}, \mathrm{PS}_{42}$, & \\
& $\mathrm{PS}_{44}, \mathrm{PS}_{46}, \mathrm{PS}_{48}, \mathrm{PS}_{50}, \mathrm{PS}_{56}, \mathrm{PS}_{61}, \mathrm{PS}_{67}, \mathrm{PS}_{68}, \mathrm{PS}_{72}, \mathrm{PS}_{73}$, \\
& $\mathrm{PS}_{74}, \mathrm{PS}_{75}, \mathrm{PS}_{76}, \mathrm{PS}_{77}, \mathrm{PS}_{78}, \mathrm{PS}_{80}$ & \\
\hline
\end{tabular}




\begin{tabular}{lll}
\hline Relational & $\mathrm{PS}_{3}, \mathrm{PS}_{9}, \mathrm{PS}_{22}, \mathrm{PS}_{23}, \mathrm{PS}_{24}, \mathrm{PS}_{26}, \mathrm{PS}_{28}, \mathrm{PS}_{32}, \mathrm{PS}_{33}, \mathrm{PS}_{34}$, & $27(\% 33,75)$ \\
& $\mathrm{PS}_{35}, \mathrm{PS}_{43}, \mathrm{PS}_{45}, \mathrm{PS}_{47}, \mathrm{PS}_{49}, \mathrm{PS}_{51}, \mathrm{PS}_{53}, \mathrm{PS}_{54}, \mathrm{PS}_{55}, \mathrm{PS}_{58}$, & \\
& $\mathrm{PS}_{60}, \mathrm{PS}_{62}, \mathrm{PS}_{63}, \mathrm{PS}_{64}, \mathrm{PS}_{66}, \mathrm{PS}_{69}, \mathrm{PS}_{71}, \mathrm{PS}_{79}$ & $2(\% 2,5)$ \\
\hline Extended abstract & $\mathrm{PS}_{38}, \mathrm{PS}_{52}$ & $80(\% 100)$ \\
\hline TOTAL & & $80(\%)$ \\
\hline
\end{tabular}

When Table 2 is examined, it is seen that most of the answers given by the preservice teachers to the $1^{\text {st }}$ question are at the level of multi-structural and relational, and only two answers are at the level of extended abstracted geometric thinking. Therefore, it can be said that mostly the answers of the preservice teachers for the mentioned question are below the relational thinking level.

The geometrical thinking level of the preservice teachers' answers to the $1^{\text {st }}$ question has been examined in detail below, along with their reasons, in line with their verbal explanations and remarkable drawings.

Some remarkable answers, which are thought to be at the pre-structural geometrical thinking level, are given in Table 3 together with their drawings and verbal explanations.

Table 3. Remarkable drawings and explanations of the answers at the pre-structural level for the $1^{\text {st }}$ question.

\begin{tabular}{|c|c|}
\hline Drawings of Preservice Teachers & Remarks by the Preservice Teacher \\
\hline & $\begin{array}{l}\text { Researcher: "Why did you create such a drawing?" } \\
\text { PS } 65: \text { "The reason why I have such an opinion is that the longer the } \\
\text { row, the less space it will occupy. By taking advantage of the } \\
\text { isometric structure, there won't be a crowd of people, } \\
\text { accumulated." }\end{array}$ \\
\hline ETRE ARA & $\begin{array}{l}\mathrm{PS}_{20} \text { : "Some warning signs will help maintain the distance between } \\
\text { people in order to protect public health and contribute to } \\
\text { precautions taken in crowded areas. A draft designed for each } \\
\text { area that needs a distance of } 2 \text { meters can be used. Thanks to this } \\
\text { draft idea, people will be more careful about the measures to be } \\
\text { taken in the name of social distance." }\end{array}$ \\
\hline Preservice teachers who do not draft & $\begin{array}{l}\mathrm{PS}_{27} \text { : "The distance between people should be } 2 \text { meters. For this, } \\
\text { we can increase the length of the waiting room. I can make a draft } \\
\text { drawing that can have a maximum number of customers by asking } \\
\text { him to put two meters away from the sides and back." }\end{array}$ \\
\hline
\end{tabular}

When Table 3 is examined, it shows social distance waiting points in the drawing of Participant 65 with only arrows. In addition, although $\mathrm{PS}_{65}$ mentions the isometric structure, it is seen that he does not mention geometric concepts in his explanations. Instead of determining the waiting points, as is reflected in the drawings and expressions Participant 20 designed a warning sign. $\mathrm{PS}_{27}$ 's visual explanations were limited to verbal expressions only. In this context, it is seen that preservice teachers do not have a geometric perspective by evaluating the problem situation only visually. For this reason, it can be said that the answers of the preservice teachers remained at the pre-structural level.

Remarkable drawings and explanations of the answers in the uni-structural geometric thinking 
level for the $1^{\text {st }}$ question are included in Table 4.

Table 4. Remarkable drawings and explanations of the answers at the uni-structural level for the $1^{\text {st }}$ question.

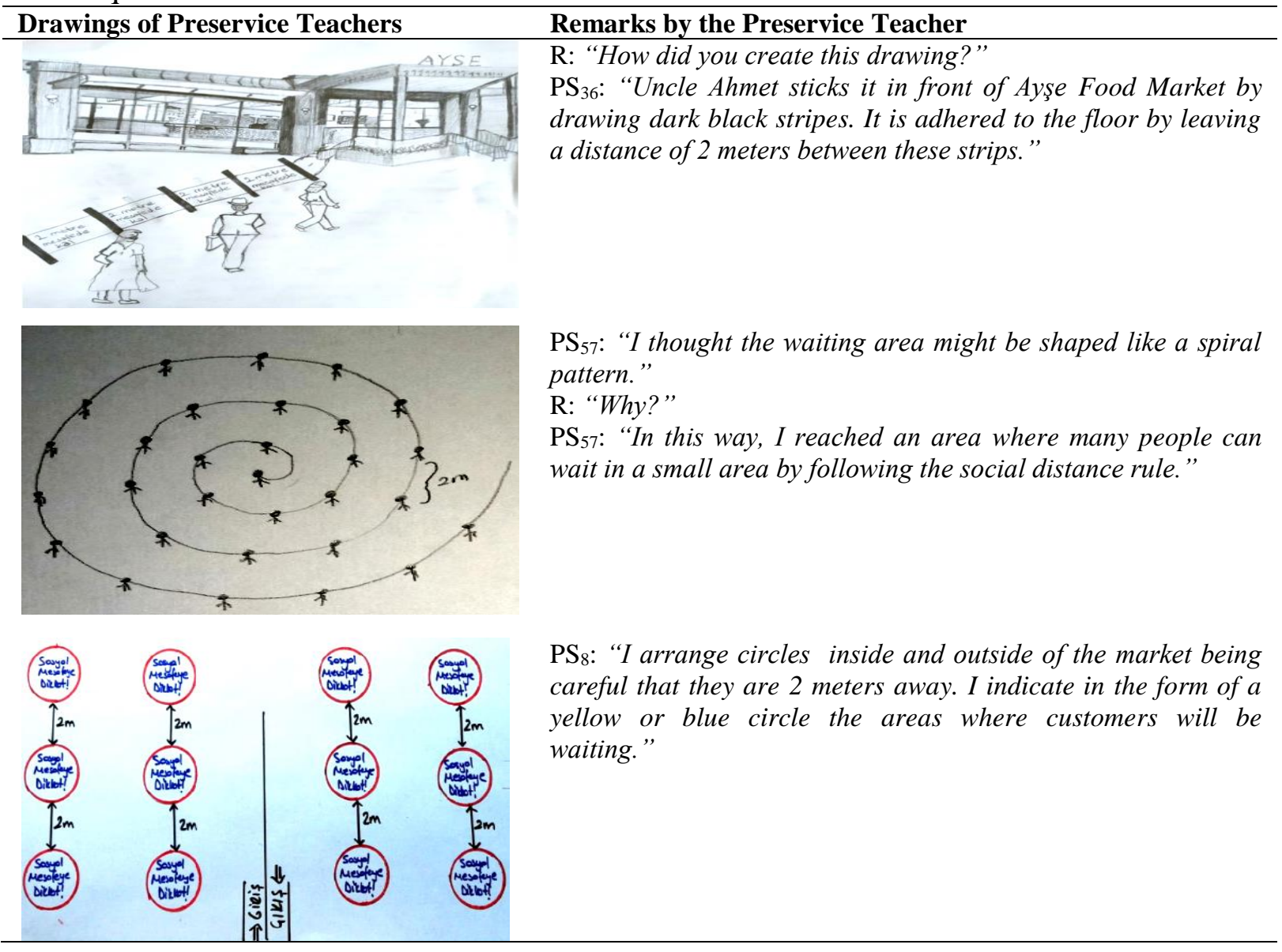

When Table 4 is examined, it is seen that $\mathrm{PS}_{36}$ and $\mathrm{PS}_{8}$ made a linear drawing while determining the waiting points, while $\mathrm{PS}_{57}$ made a spiral drawing. $\mathrm{PS}_{36}$, who made a linear drawing, formed one row and $\mathrm{PS}_{8}$ formed four rows. However, $\mathrm{PS}_{8}$ did not specify the horizontal distances of the points she determined as "social distance points" that are distant from each other and did not make an explanation for this. On the other hand, although $\mathrm{PS}_{57}$ claimed that waiting points in accordance with the social distance rule can be created in a small area with a spiral drawing, he did not make any explanations about the distance between the inner spiral and outer spiral waiting points. Therefore, it is seen that the $\mathrm{PS}_{8}, \mathrm{PS}_{36}$ and $\mathrm{PS}_{57}$ preservice teachers focus only on the distance between the ordered people, based on their drawings and explanations. For this reason, the absence of any expressions in the drawings and explanations of the preservice teachers regarding the distance between other waiting points other than the sequential waiting points shows that they approached the problem situation at a uni-structural level.

Remarkable drawings and explanations of the answers at the multi-structural geometric thinking level for the $1^{\text {st }}$ question are included in the Table 5. 
Table 5. Remarkable drawings and explanations of the answers at the multi-structural level for the $1^{\text {st }}$ question.

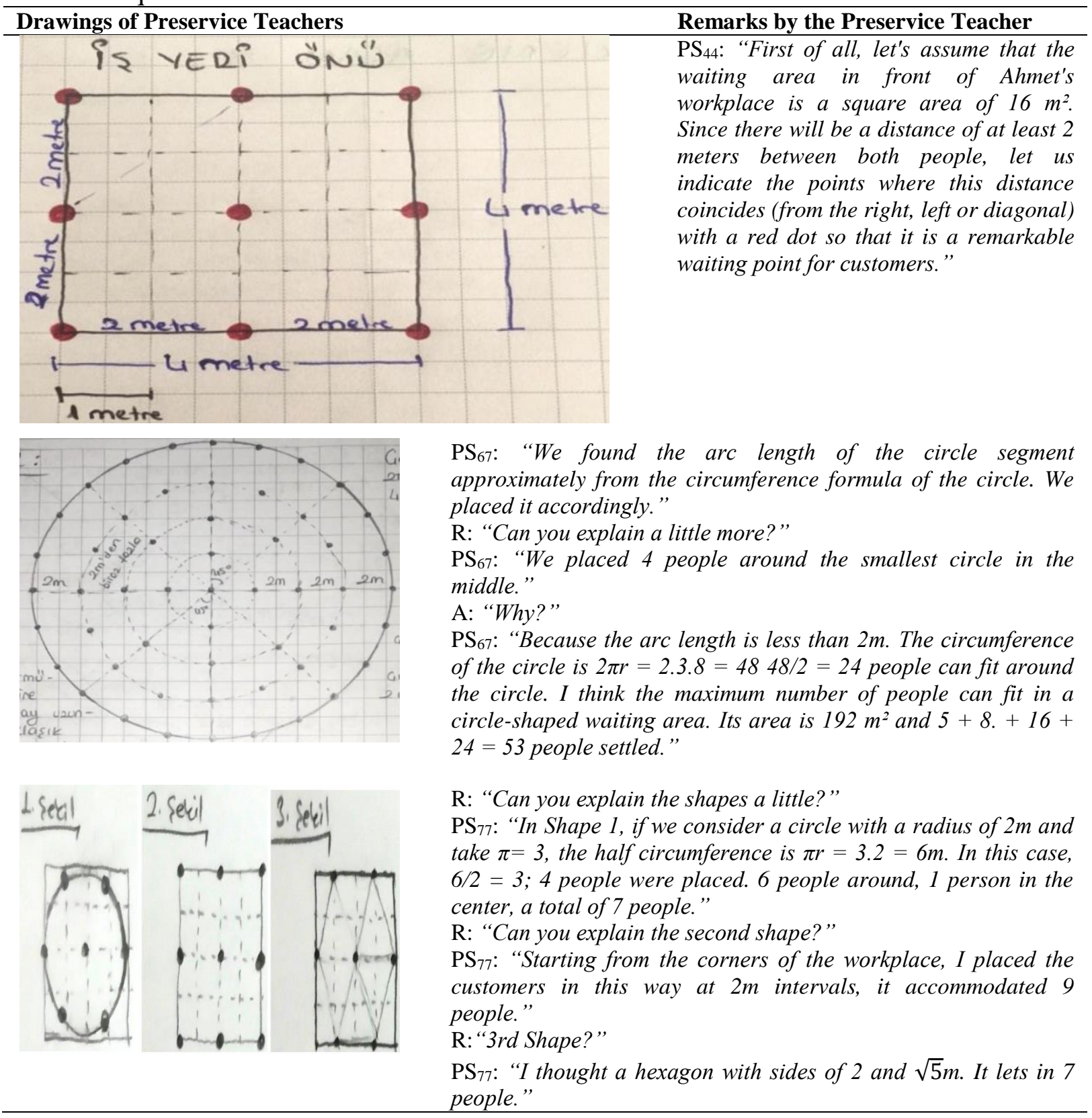

When Table 5 is examined, it is seen that $\mathrm{PS}_{44}$ aims to form a square-shaped structure, $\mathrm{PS}_{67}$ a circle shaped structure and $\mathrm{PS}_{77}$ intended to address the maximum number of people by trying many situations. The preservice teachers explained their drawings by supporting them with calculations. For example, $\mathrm{PS}_{44}$ 's statement about this situation is as follows:

$\mathrm{PS}_{44}$ : "Since there will be a distance of at least 2 meters between both people, let us indicate the points where this distance coincides from the right, left or diagonal with a red $\operatorname{dot} \ldots$.

As can be seen from the drawing of $\mathrm{PS}_{44}$ and the statement above, the distance between the persons should be at least two meters. However, $\mathrm{PS}_{44}$ did not make any explanation for the maximum number of people requested in the question. Although PS67 stated that "I thought 
about the maximum number of people that can fit in a circle-shaped waiting area." the distance between the waiting points in different circles that he created is more than two meters shows that the area could not be used in the optimal way. On the other hand, $\mathrm{PS}_{77}$, thinks that the second figure among the three different drawings she created is appropriate. However, it is seen that she cannot make the right choice because she does not compare the number of people per unit area. As can be seen, preservice teachers made drawings showing the relationship between more than two people in detail and made multi-structural geometric drawings that exceed one dimension between the waiting points. However, although the preservice teachers planned to target the maximum possible number of people, there are deficiencies in their drawings and explanations regarding the detail that the distance between all waiting points should be equal and two meters. Therefore, it can be said that the answers of the preservice teachers are at the level of multi-structural geometric thinking.

Remarkable drawings and explanations of the answers at the relational geometric thinking level for the $1^{\text {st }}$ question are included in Table 6.

Table 6. Remarkable drawings and explanations of the answers at the relational level for the $1^{\text {st }}$ question.

Remarks by the PreserviceTeacher
$\mathrm{PS}_{22}:$ "Uncle Ahmet can reach a solution by drawing circles with
a radius of 1 meter and placing 1 customer in the center of each
circle."

When the Table 6 is examined, $\mathrm{PS}_{22}$ designed the waiting points with circles of one meter radius and $\mathrm{PS}_{43}$ with circles of two meters radius. On the other hand, it is seen that $\mathrm{PS}_{64}$ designed waiting points with equilateral triangles with sides of two meters. Drawings and explanations show that preservice teachers reach the correct result with different techniques. The preservice teachers' suggestions for a drawing by evaluating the relationship between waiting points from a correct perspective show that they approached the problem situation at the level of relational geometric thinking.

The answers at the level of extended abstract geometric thinking in the $1^{\text {st }}$ question were given by only two preservice teachers. Drawings and explanations of these answers are included in Table 7. 
Table 7. Drawings and explanations of the extended abstract level answers for the $1^{\text {st }}$ question

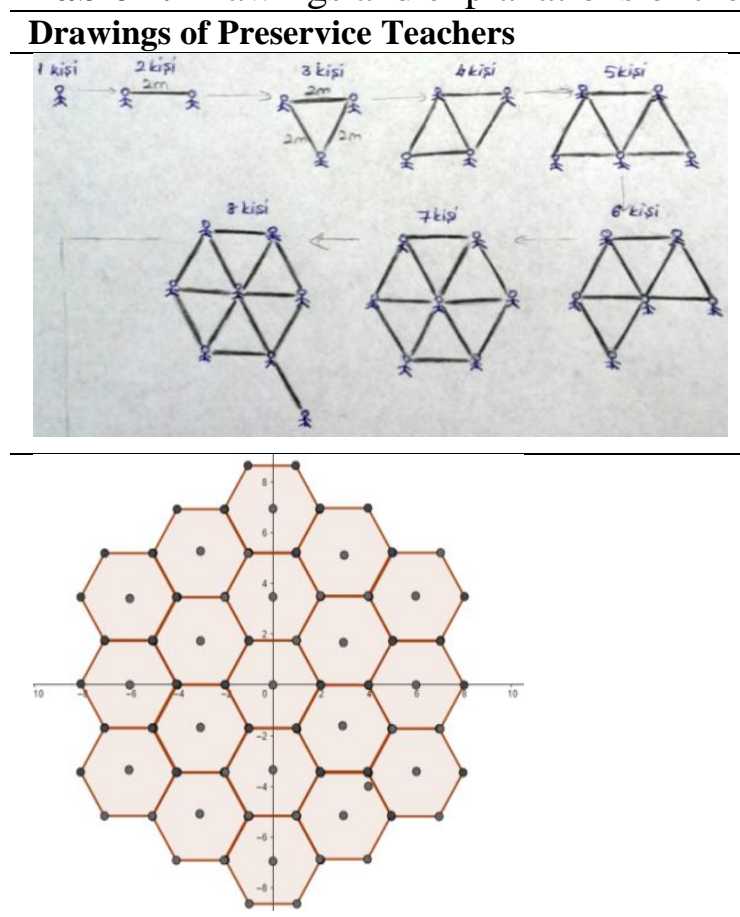
Remarks by the Preservice Teacher

$\mathrm{PS}_{38}$ : "The shape it will use is a regular hexagon." $\mathrm{R}:$ "Why?"

$\mathrm{PS}_{38}$ : "In nature, bees make honeycombs in the shape of a regular hexagon. Because a honeycomb consisting of hexagonal cells is the shape that provides the most storage with the least wax. The regular hexagon shown in the figure consists of equilateral triangles. This ensures that the distance between each person is $2 \mathrm{~m}$. When a regular hexagonal waiting area is created, people are arranged like this."

R: "How did you create this drawing?"

$\mathrm{PS}_{52}$ : "All sides of a regular hexagon are the same length and all angles are equal. Moreover, it is seen to be symmetrical when viewed from all sides. With a regular hexagon, we can cover our area with no gaps. We can set them as waiting points for people in the center and corners. Thus, the distance between people both in the center and in the corners close to it becomes 2 meters. Only with regular hexagons, squares, and equilateral triangles, can we cover any plane we want without any gaps. Thus, it allows many people to wait in a small area. Bees can be inspired to make honeycomb eyes out of hexagons. This way, bees use less wax and do less work, which means they behave economically. The most suitable shape for maximum use of a space is a hexagon. The hexagonal chamber both stores the most honey and uses the least wax when building."

When Table 7 when examined, it is seen that $\mathrm{PS}_{38}$ and $\mathrm{PS}_{52}$ pay attention to the maximum waiting point while creating their drawings and support their arguments with correct explanations and through the geometric concepts they use while determining the waiting points. In addition to this, unlike other stages, it is seen that preservice teachers go beyond the problem with the knowledge that the "bee comb" context requires the most volume, the least space and material, and establishes a link between the real life and the problem situation. Therefore, the preservice teachers' presenting their correct solutions with appropriate supportive examples from daily life shows that their answers are at the level of extended abstracted geometric thinking.

Generally speaking, considering that most of the answers given to the first problem situation in the study are at the level of pre-structural, uni-structural and multi-structural thinking, it can be said that most of the answers reflect quantitative learning. In addition, it can be said that the inability of preservice teachers to look at the question from a broad perspective, their interpretations made in a single way in their minds prevented them from thinking contextually and going beyond the question.

\section{Findings and Comments in Question 2}

The $2^{\text {nd }}$ question about "Social Distance" that preservice teachers are asked to answer is given below. 


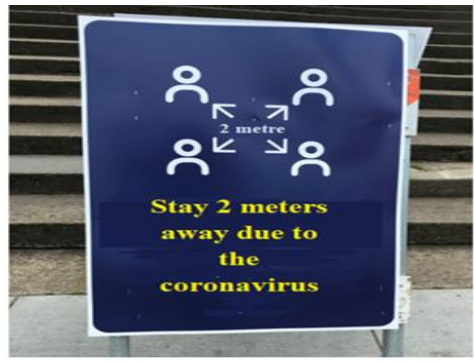

What are your thoughts on the warning signboard prepared to draw attention to the 2 meters social distance rule due to coronavirus?

Figure 2. Question $2^{\text {nd }}$ with the content of "social distance"

The geometric thinking levels according to the SOLO taxonomy of the answers given by the preservice teachers for the $2^{\text {nd }}$ question in Figure 2 are shown in Table 8.

Table 8. Analysis of preservice teachers' answers to the $2^{\text {nd }}$ question according to the SOLO taxonomy.

\begin{tabular}{|c|c|c|}
\hline Thinking Levels & Preservice Teachers & Number of Participants \\
\hline Pre-structural & $\begin{array}{l}\mathrm{PS}_{1}, \mathrm{PS}_{2}, \mathrm{PS}_{4}, \mathrm{PS}_{5}, \mathrm{PS}_{6}, \mathrm{PS}_{7}, \mathrm{PS}_{8}, \mathrm{PS}_{10}, \mathrm{PS}_{11}, \mathrm{PS}_{12}, \mathrm{PS}_{14}, \\
\mathrm{PS}_{16}, \mathrm{PS}_{17}, \mathrm{PS}_{20}, \mathrm{PS}_{22}, \mathrm{PS}_{23}, \mathrm{PS}_{26}, \mathrm{PS}_{28}, \mathrm{PS}_{27}, \mathrm{PS}_{30}, \mathrm{PS}_{31}, \\
\mathrm{PS}_{33}, \mathrm{PS}_{36}, \mathrm{PS}_{37}, \mathrm{PS}_{39}, \mathrm{PS}_{40}, \mathrm{PS}_{42}, \mathrm{PS}_{43}, \mathrm{PS}_{44}, \mathrm{PS}_{45}, \mathrm{PS}_{46}, \\
\mathrm{PS}_{47}, \mathrm{PS}_{48}, \mathrm{PS}_{50}, \mathrm{PS}_{51}, \mathrm{PS}_{53}, \mathrm{PS}_{58}, \mathrm{PS}_{59}, \mathrm{PS}_{60}, \mathrm{PS}_{61}, \mathrm{PS}_{62}, \\
\mathrm{PS}_{66}, \mathrm{PS}_{67}, \mathrm{PS}_{68}, \mathrm{PS}_{69}, \mathrm{PS}_{71}, \mathrm{PS}_{72}, \mathrm{PS}_{74}, \mathrm{PS}_{75}, \mathrm{PS}_{78}, \mathrm{PS}_{79}, \\
\mathrm{PS}_{70}\end{array}$ & $52(\% 62,5)$ \\
\hline Uni-structural & $\mathrm{PS}_{29}, \mathrm{PS}_{65}$ & $2(\% 2,5)$ \\
\hline Multi-structural & $\begin{array}{l}\mathrm{PS}_{3}, \mathrm{PS}_{13}, \mathrm{PS}_{18}, \mathrm{PS}_{19}, \mathrm{PS}_{25}, \mathrm{PS}_{34}, \mathrm{PS}_{38}, \mathrm{PS}_{41}, \mathrm{PS}_{49}, \mathrm{PS}_{52}, \\
\mathrm{PS}_{54}, \mathrm{PS}_{56}, \mathrm{PS}_{73}\end{array}$ & $13(\% 16,25)$ \\
\hline Relational & $\begin{array}{l}\mathrm{PS}_{9}, \mathrm{PS}_{15}, \mathrm{PS}_{21}, \mathrm{PS}_{24}, \mathrm{PS}_{32}, \mathrm{PS}_{35}, \mathrm{PS}_{55}, \mathrm{PS}_{57}, \mathrm{PS}_{63}, \mathrm{PS}_{64}, \\
\mathrm{PS}_{76}, \mathrm{PS}_{77}, \mathrm{PS}_{80}\end{array}$ & $13(\% 16,25)$ \\
\hline Extended abstract & - & $0(\% 0)$ \\
\hline TOTAL & & $80(\% 100)$ \\
\hline
\end{tabular}

When Table 8 is examined, most of the answers that the preservice teachers gave to the second question are at the pre-structural level. In addition, there is no answer at the level of extended abstract geometric thinking. Therefore, when Table 7 is examined in general, it is striking that most of the answers given to the question in question are below the level of relational geometric thinking. The geometrical thinking level of the preservice teachers' answers to the $2^{\text {nd }}$ question has been examined in detail below, along with their reasons, in line with their verbal explanations and remarkable drawings.

Looking at the answers that are thought to be at the pre-structural geometrical thinking level for the $2^{\text {nd }}$ question it was determined that the preservice teachers did not draw geometrical drawings, they only made verbal explanations. The remarkable explanations of some preservice teachers are given below:

$\mathrm{PS}_{20}:$ "... some more striking items should be used in the signboard. It should consist of more interesting colors."

$\mathrm{PS}_{27}$ : "The warning signboard is nice in terms of raising awareness and appeals to everyone ..."

$\mathrm{PS}_{36}$ : “... emphasizes how important the distance rule is for our health." 
When the expressions of the preservice teachers were examined, it was observed that $\mathrm{PS}_{20}$ stated that the signboard should be colored, and $\mathrm{PS}_{27}$ and $\mathrm{PS}_{36}$ stated that the signboard reflected the social distance rule correctly. In this context, it can be said that the problem situation is approached only in terms of shape, since the expressions "signboard is nice" or "should be colored" are thought to be at the level of pre-structural geometric thinking. Therefore, the lack of a geometric explanation in verbal expressions shows that the answers are at the pre-structural level. The answers at the uni-structural geometric thinking level for the $2^{\text {nd }}$ question were given by only two preservice teachers. Drawings and explanations of these answers are included in Table 9.

Table 9. Remarkable drawings and explanations of the answers at the uni-structural geometric thinking level for the $2^{\text {nd }}$ question.

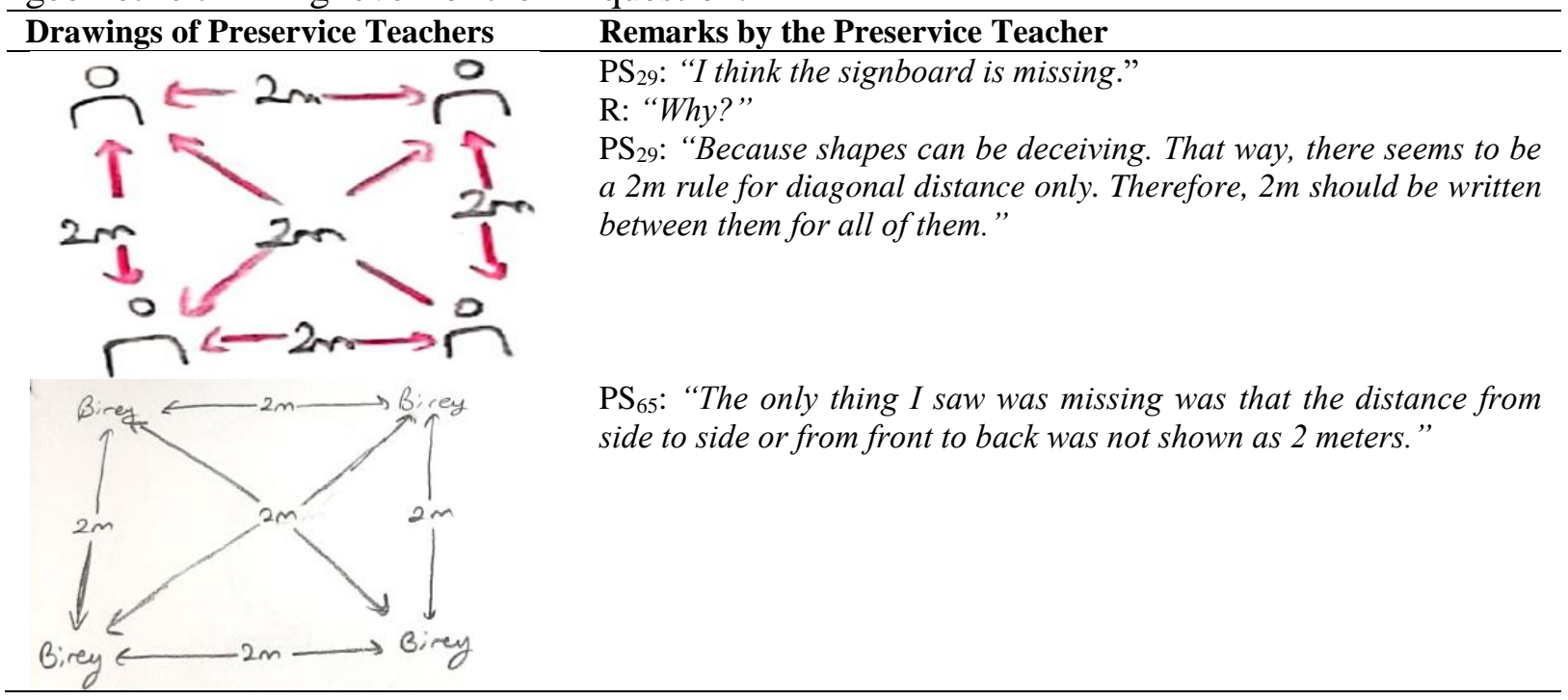

When Table 9 is examined, $\mathrm{PS}_{29}$ and $\mathrm{PS}_{65}$ make corrections with the drawings they make by expressing that the signboard given in the question is missing. However, based on the drawings and explanations of the preservice teachers, it is seen that they made an addition on the geometrical dimension on the figure for a distance of only two meters. Therefore, $\mathrm{PS}_{29}$ and $\mathrm{PS}_{65}$ do not evaluate the shape multidimensionally or give detailed information about the drawing. Remarkable drawings and explanations of the answers in the multi-structural geometric thinking level for the $2^{\text {nd }}$ question are included in the Table 10.

Table 10. Remarkable drawings and explanations of the answers at the multi-structural geometric thinking level for the $2^{\text {nd }}$ question.

\begin{tabular}{ll}
\hline Drawings of Preservice Teachers & Remarks by the Preservice Teacher \\
\hline$\sqrt{2} \mathrm{~m}$ & $\begin{array}{l}\mathrm{PS}_{38}: \text { "On the sign, people are arranged in a square. But in a } \\
\text { square with a diagonal length of } 2 \mathrm{~m} \text {, the sides would be } \sqrt{2} \mathrm{~m} . \\
\text { Its approximate value corresponds to } 1.41 \text { m. It is less than } 2 \\
\text { m. Therefore, a mistake is made in the social distance rule." }\end{array}$ \\
& $\begin{array}{l}\mathrm{PS}_{52}: \text { "The distance between the diagonals on the sign has } \\
\text { been taken as } 2 \mathrm{~m} \text { and the distance of the people standing next } \\
\text { to each other or under the other is not } 2 \text { meters. They stop at a } \\
\text { less distance. This is a false representation like the diagonals } \\
\text { of the square are } 2 \mathrm{~m} \text { and the sides are } 2 \mathrm{~m} . "\end{array}$ \\
\hline
\end{tabular}


When the Table 10 is examined it is observed that Preservice teachers $\mathrm{PS}_{38}$ and $\mathrm{PS}_{52}$ evaluate the shape as a square and indicate that if the diagonal is two meters according to the Pythagorean Theorem, the side lengths of the square are less than two meters. It is seen that preservice teachers can look at the figure holistically and explain correctly by using geometric concepts while expressing their thoughts. In this context, it can be said that they think geometrically at a multi-structural level, as they evaluate the shape in many ways. Looking at the drawings and explanations of the preservice teachers, it is seen that they expressed the error geometrically but did not suggest the correct shape for the signboard. Remarkable drawings and explanations of the answers in the relational geometric thinking level for the $2^{\text {nd }}$ question are included in the Table 11.

Table 11. Remarkable drawings and explanations of the answers at the relational geometric thinking level for the $2^{\text {nd }}$ question.

\begin{tabular}{ll}
\hline Drawings of Preservice Teachers & Remarks by the Preservice Teacher \\
\hline
\end{tabular}

$\mathrm{PS}_{64}$ and $\mathrm{PS}_{57}$ have made correct criticisms of the signboard with the Pythagorean theorem by evaluating the shape in the signboard as a square. At the same time, it is seen that these preservice teachers made a suggestion for a correction to the signboard, different from other geometric thinking levels. It was observed that the preservice teachers could not answer at the level of extended abstract geometric thinking for the $2^{\text {nd }}$ question. Considering the drawings and expressions of the related preservice teachers, they evaluated the shape in the signboard as only a square in a geometric perspective and accordingly criticized it making a suggestion. This situation shows that the preservice teachers could not approach the shape from a different point of view and could not bring multi-faceted criticisms. Therefore, since the level of extended abstract goes beyond the problem and requires the ability to offer different solutions from daily life, it is thought that no preservice teacher could reached this level for this question.

Considering that most of the answers given to the question in general are below the relational geometric thinking level, it can be said that most of the answers reflect quantitative learning.

\section{Discussion and Conclusion}

In this study, which aimed to examine the geometric thinking levels of middle school mathematics preservice teachers for social distance problem situations according to the SOLO taxonomy, two questions were asked to the preservice teachers. In the first question, preservice teachers were asked to come up with a draft drawing indicating the waiting points in accordance with the social distance rule (at least two meters), taking into account the maximum number of people. Taking a glance at the answers given by the preservice teachers 
to this question it was observed that they are mostly at the multi-faceted (37 preservice teachers) and relational level (27 preservice teachers), very few of them were at the prestructural level (6 preservice teachers), uni-structural ( 2 preservice teachers) and extended abstract level ( 2 preservice teachers). When the answers of the preservice teachers at the multi-structural level are examined it was detected that they thought about the connection between social distance points, but did not explain the relationship between the data on the maximum number of people or reached the wrong conclusions. This situation creates some inconsistencies in the answers of the multi-structural level. As a matter of fact, in the study by Göktepe and Özdemir (2013) examining the spatial visualization skills of pre-service mathematics teachers with the SOLO model, it was found that the preservice teachers were predominantly at a very structural level. In addition, in the aforementioned study, it was stated that preservice teachers could use data in their answers, but their inability to grasp the relationship between data caused some deficiencies. In this study, a similar situation is also valid for the relational level. In this study, a similar situation is valid for the relational geometric thinking level. In the answers thought to be at the level of relational geometric thinking it was spotted that the relationship between the data on social distance points and the maximum number of people could be explained, but the connection between the given problem situation and real life could not be established. As a matter of fact, this result is in line with the results of some studies on the SOLO taxonomy (Çelik, 2007; Groth \& Berner, 2006; Konyalıhatipoğlu, 2016; Lian \& İdris, 2006; Pegg \& Davey, 1998). In the study by Çelik (2007), in which algebraic thinking skills of pre-service mathematics teachers were examined with SOLO taxonomy, it was determined that most preservice teachers were below the relational structural level. Çelik (2007) explains that the reason for this situation is that preservice teachers cannot integrate their knowledge and skills in a consistent structure. According to Pegg and Davey (1998), as the transition from uni-structural thinking level to the extended abstract thinking level increases, the level of individuals using and associating data and looking at data from a wider perspective increases. In addition, in the study by Pegg and Davey (1998), it is stated that the most difficult transition is from the relational level to the extended abstract level. This situation supports why there are fewer extended abstract answers in the study conducted. According to Çetin and Illhan (2016, p. 862), responses at the pre-structural thinking level include expressions that are not relevant to the subject, while at the uni-structural thinking level, basic skills such as explaining, ordering and counting are shown. On the other hand, according to Lucander, Bondermark, Brown, and Knutsson (2010), the number of details in student responses indicates the quantitative aspect of structural complexity whereas the level of associating the details with each other reflects its qualitative aspect. By Çetin and İlhan (2016, p. 862) pre-structural, uni-structural, multi-structural thinking levels are expressed as quantitative learning, and relational and abstracted thinking levels are expressed as qualitative learning. Therefore, considering that most of the answers to the first problem situation in this study are at the level of pre-structural, uni-structural and multi-structural thinking, it can be said that most of the answers reflect quantitative learning.

In the problem situation in the second question of the study, the answers of the preservice teachers were examined about the sign prepared to draw attention to the fact that the social distance should be two meters due to the coronavirus. An important part of the answers given to this question is at the level of pre-structural (52 preservice teachers) geometric thinking. The answers of other preservice teachers are at the level of multi-structural (13 preservice teachers), relational (13 preservice teachers), uni-structural (2 preservice teachers), and there is no answer at the level of extended abstract geometric thinking. It was observed that the preservice teachers whose answers were at the pre-structural level offered some suggestions for the signboard to be appropriate or to be more striking, but they did not make geometric 
explanations. In the answers at the level of uni-structural thinking, it was determined that they proposed only the social distance (two meters) should be written all over the figure, and the resulting shape was not evaluated multi-structural. As a matter of fact, this situation is parallel to the results obtained from some studies (Jurdak, 1991; Lian \& Yew, 2012). In the study where Jurdak (1991) showed the relationship between SOLO taxonomy levels and Van Hiele levels, it was stated that the visual level, which is the beginning of Van Hiele geometric thinking levels, was the uni-structural level in the SOLO taxonomy. In addition, in the study conducted by Jurdak (1991), it was stated that the pre-structural level known as the initial level of the SOLO taxonomy did not have a counterpart in Van Hiele geometric thinking levels. Therefore, the absence of geometric expressions in the pre-structural answers in this study is supported by the results of the studies in the relevant literature. On the other hand, it is remarkable that in the answers given at the multi-structural and relational level, which constitutes the other majority, to the second question, the preservice teachers consider the shape in the signboard as a square and criticize it based on the Pythagorean Theorem. In addition, it was seen that the answers at the multi-structural level were only aimed at finding the error of the shape based on the Pythagorean Theorem, while the relational level answers also offered an additional suggestion for correcting the shape. In this respect, it can be said that the preservice teachers' criticisms and explanations on the shape in the signboard are correct but they cannot look at the question from a broad perspective because there is no data indicating that the shape given in the question is square or that it would require them to use the Pythagorean Theorem. Therefore, it can be said that the preservice teachers who gave multi-structural and relational level answers applied the Pythagorean Theorem directly without examining the figure in the sign in detail. This may be due to the preservice teachers' learning the square shape as a prototype and trying to apply the Pythagoras Theorem that they had memorized to quickly reach a solution. As a matter of fact, in the study by Köse (2018) examining the SOLO taxonomy levels of preservice teachers with high-level spatial thinking skills according to their thinking structures, it was determined that very few of those who prefer visual pictorial questions (geometric thinking structure) consistently associate their evaluations and use mathematical generalizations. In addition, it can be said that the inability of preservice teachers to look at the question from a broad perspective, their interpretation in a single way in their minds prevented them from thinking contextually and going beyond the question. This situation explains the finding that there is no answer at the extended abstract level in the case of the second problem. As a matter of fact, this result is in line with the results of some studies on the SOLO taxonomy (Güven, Ardıç, Yıldız, \& Demir, 2012; Karlı 2019; Pittalis, Christou, \& Papageorgiou, 2003). In the study by Güven, Ardiç, Y1ldız, \& Demir (2012), in which the statistical literacy levels of 8th grade students for central tendency and spread measures were examined according to the SOLO taxonomy, it was determined that there was no answer at the extended abstract level because the students were limited to the available information. Considering the fact that the answers to the second problem situation are mostly pre-structural and multi-structural and there is no answer at the extended abstract level, it can be said that the answers of the preservice teachers involve quantitative learning.

As a result, when the answers given by the preservice teachers to both questions were examined, it was found that the answers were generally below the relational level. As a matter of fact, this situation is compatible with the results of many studies on different subjects of mathematics using the SOLO taxonomy (Akkaş, 2009; Bağdat, 2013; Çelik, 2007; Güven, Ardıç, Yıldız, \& Demir, 2012; Göktepe, 2013; Özdemir \& Göktepe-Y1ldız, 2015; Karlı, 2019). It was determined that a significant part of the answers given in the study reflected quantitative learning since the geometric thinking level was below the relational structure. This shows that most of the preservice teachers participating in the study can use their data 
and existing knowledge in the determined geometry problem situations, but there are difficulties in the integration and organization of these data and information.

\section{Suggestions}

In line with the data obtained from the study, the preservice teachers' answers to the specific situation were examined according to the SOLO taxonomy. Comparisons can be made by analyzing the same data according to other taxonomies. In this way, the special situation determined can be approached from a different perspective and additions can be made to the aspects of the SOLO taxonomy that are thought to be missing.

In this study, there is no aim to improve the geometric thinking levels of preservice teachers. In different studies, researchers can examine the change in levels according to the SOLO taxonomy by making applications to improve geometric thinking levels.

It was determined that the answers given to the geometry questions determined within the scope of this study mostly reflected quantitative learning. It was determined that the answers reflecting qualitative learning requiring the use of contextual thinking skill were few. According to MoNE (2016), it is known that we are not at the desired level in The Program International Student Assessment [PISA, 2015] report, which is an international comparative exam. In the math questions in the exam, open-ended, standard, contextual, visual representation and verbal data-weighted problems are mainly used. Multiple choice questions are used in national exams applied in our country. This situation affects our learning culture and causes teachers to create their lessons for a multiple choice test structure. The lack of diversity in teaching in this standardized perspective makes students unable to transfer their knowledge to other situations. In the study, it is seen that open-ended questions directed to preservice teachers contribute to revealing geometric thoughts. In this context, it is thought that teachers' use of open-ended questions in their lessons will contribute to students' use of mathematics as a language of communication and to transfer mathematical knowledge to other areas and sciences. In this respect, open-ended mathematical literacy questions should be included in teaching frequently in order to develop contextual thinking skills, which is an important skill for mathematics literacy.

\section{References}

Akbaş-Ertem, A. (2016). Evaluation of the learning of the students of vocational high schools in computer assisted environment about the concept of 'limit and continuity' by SOLO taxonomy. (Unpublished doctoral dissertation). Black Sea University, Trabzon.

Akkaş, E. N. (2009). Investigation of the middle school students' statistical thinking. (Unpublished master's thesis). Abant İzzet Baysal University, Bolu.

Aristoteles, (1993). Aristoteles, Metafizik Cilt II, (Trans. A. Arslan). İzmir: Ege University Press, İzmir.

Bağdat, O. (2013). Investigation of the 8th grade students' algebraic thinking skills with SOLO taxonomy. (Unpublished doctoral dissertation). Eskişehir Osmangazi University, Eskişehir.

Biggs, J. \& Collis, K. (1991). Multimodal learning and the quality of intelligent behaviour. $H$. Rowe, Intelligence (Ed.), New Jersey: Reconceptualization and Measurement, Laurence Erlbaum Assoc.

Biggs, J. B., \& Collis, K. F. (1982). Evaluating the quality of learning: The SOLO taxonomy (Structure of the observed learning outcome). New York: Academic Press. 
Brabrand, C., \& Dahl, B. (2009). Using the SOLO taxonomy to analyze competence progression of university science curricula. Higher Education, 58(4), 531-549. https://doi.org/10.1007/s10734-009-9210-4

Bulut, İ., Öner-Sünkür, M., Oral, B., \& İlhan, M. (2012). Analysis of the relationship between geometrical thinking levels and intelligence domains of 8th grade students. Electronic Journal of Social Sciences, 11(41), 161-173.Retrieved from https://dergipark.org.tr/en/pub/esosder/issue/6155/82709

Callingham, R. A. (1999). Developing performance assessment tasks in mathematics: A case study. Paper presented at the Making the Difference (Proceedings of the $22^{\text {nd }}$ Annual Conference of the Mathematics Education Research Group of Australasia, pp. 135-142). MERGA: Adelaide, SA.

Çelik, D. (2007). Analytical examination of the preservice teachers' algebraic thinking skills. (Unpublished doctoral dissertation). Black Sea University, Trabzon.

Çetin, B., \& İlhan, M. (2016). SOLO taksonomisi [SOLO Taxonomy]. In Bingölbali, E., Özarslan, S., \& Zembat İ. Ö. (Ed.), Matematik eğitiminde teoriler [Theories in mathematics education] (p. 861-879). Ankara: Pegem Academy.

Cherowitzo, B. (2006). "Geometric Constructions." [Online] Retrieved on 25-January-2021., at URL http://www-math.cudenver.edu/ wcherowi/courses/m3210/lecchap5.pdf.

Denzin, N. K., \& Lincoln, Y. S. (Ed.). (1998). Collecting and interpreting qualitative materials. Thousand Oaks, Calif: Sage Publications.

Duatepe, A. (2004). The effects of drama based instruction on seventh grade students' geometry achievement, Van Hiele geometric thinking levels, attitude toward mathematics and geometry. (Unpublished doctoral dissertation). Middle East Technical University, Ankara.

Erduran, A. \& Yeşildere, S. (2010). The use of a compass and straightedge to construct geometric structures. Elementary Education Online, 9(1), 331-345.

Fennema, E., \& Loef, F. M. (1992). Teachers' knowledge and its impact. D. A. Grouws, (Ed.), Handbook of research on mathematics teaching and learning (147-164). NewYork: Macmillan.

Fidan, Y. \& Türnüklü, E. (2010). Investigation of some types of variables in the depths of primary school 5th grade students. Pamukkale University Journal of Education, 27(27), 185-197.Retrieved from https://dergipark.org.tr/tr/pub/pauefd/issue/11116/132940

Gökbulut, Y., Sidekli, S., \& Yangin, S. (2010). Researching preservice primary teacher's van Hiele geometric thinking levels according to some variables (graduation type of high school, high school sphere, high school average, Student Selection Exampoints, university academic average and sex). Turkish Journal of Educational Sciences, 8(2), 375-396. Retrieved from https://dergipark.org.tr/en/pub/tebd/issue/26104/275039

Göktepe, S. (2013). Examining the spatial abilities of pre-service mathematics teachers with a solo model. (Unpublished doctoraldissertation).Marmara University, İstanbul.

Göktepe, S., \& Özdemir, A. Ş. (2013). Examing elementary mathematics teacher candidates' special visualization skills by SOLO model. KALEM International Journal of Educational and Human Sciences, 3(2), 91-146. https://doi.org/10.23863 / kalem.2017.26

Groth, R. E., \& Bergner, J. A. (2006). Preservice elementary teachers' conceptual and procedural knowledge of mean, median, and mode. Mathematical Thinking and Learning, 8(1), 37-63. https://doi.org/10.1207/s15327833mt10801_3

Güven, B., Ardıç, E. Ö., Yı1maz, B., \& Demir, E. (2012, June). Examination of the statistical literacy levels of primary school 8th grade students on central tendency and spread measures according to solo taxonomy. Paper presented at the meeting of X. National 
Science and Mathematics Education Congress, Niğde, Turkey. Abstract retrieved from https://www.pegem.net/Akademi/bildiri_detay.aspx?id=135891

Halat, E. (2006). Sex-related differences in the acquisition of the van hiele levels and motivation in learning geometry. Asia Pacific Education Review, 7(2), 173-183. https://doi.org/10.1007/BF03031541

Hvizdo, M. M. (1992). A study of the effect of spatial ability on geometry grades. (Unpublished master's thesis). Southern Connecticut State University, Connecticut.

İlhan, M. (2015). The identification of rater effects on open-ended math questions rated through standard rubrics and rubrics based on the SOLO taxonomy in reference to the many facet Rasch model. (Unpublished doctoral dissertation). Gaziantep University, Gaziantep.

Jurdak, M. (1991). Van Hiele levels and the SOLO taxonomy†. International Journal of Mathematical Education in Science and Technology,22(1), 57-60. https://doi.org/10.1080/0020739910220109

Kahan, J. A., Cooper, D. A., \& Bethea, K. A. (2003). The role of mathematics teachers' content knowledge in their teaching: A framework for research applied to a study of student teachers. Journal of Mathematics Teacher Education, 6, 223-252. https://doi.org/10.1023/A:1025175812582

Karl1, M.G. (2019). Investigation of the 7th grade students' proportional thinking skills with SOLO Taxonomy. (Unpublished master's thesis). Tokat Gaziosmanpaşa University, Tokat.

Kılıç, Ç. (2003). The Effect of teaching geometry based on Van Hiele Levels on the acedemic success, attitudes and recall levels of the 5 th grade primary school students in mathematics course. (Unpublished master's thesis). Anadolu University, Eskişehir.

Konyalıhatipoğlu, M. E. (2016). A SOLO taxonomy research on holistic and analytic thinking styles of seventh grade secondary school students. (Unpublished master's thesis). Recep Tayyip Erdoğan University, Rize.

Köse, O. (2018). Determination of SOLO taxonomy levels of mathematics teacher candidates with high level spatial ability accordingto thinking structures. (Unpublished master's thesis). Selçuk University, Konya.

Lian, L. H. \& Idris, N. (2006). Assessing algebraic solving ability of form four students. International Electronic Journal of Mathematics Education (IEJME), 1(1), 55-76.

Lian, L.H., \& Yew, W. T. (2012). Assessing algebraic solving ability: A theoretical framework. International Education $\quad$ Studies, 5(6), 177. https://doi.org/10.5539/ies.v5n6p177

Lloyd, G. M., \& Wilson, M. (1998). Supporting innovation: The impact of a teacher's conceptions of functions on his implementation of a reform curriculum. Journal for Research in Mathematics Education, 29(3), 248-274. https://doi.org/10.2307/749790

Lucander, H., Bondemark, L., Brown, G., \& Knutsson, K. (2010). The structure of observed learning outcome (Solo) taxonomy: A model to promote dental students' learning: The SOLO taxonomy: a model to promote learning. European Journal of Dental Education, 14(3), 145-150. https://doi.org/10.1111/j.1600-0579.2009.00607.x

Mekouar, D. (2020). https://www.voanews.com/science-health/coronavirus-outbreak/howsocial-distancing-can-impact-your-mental-health 25 Ocak 2021.

Miles, M. B., \& Huberman, A. M. (1994). Qualitative data analysis: An expanded sourcebook. London: Sage.

Ministry of National Education (MoNE), (2009a). Mathematics lesson (grades 1-5) curriculum, Ankara.

Ministry of National Education (MoNE), (2009b). Mathematics lesson (grades 6-8) curriculum, Ankara. 
Ministry of National Education (MoNE), (2013). Mathematics applications lesson (5th, 6th, 7 th and 8th grades) curriculum, Ankara.

Ministry of National Education (MoNE), (2016). PISA 2015 International Student Assessment Program National Report, Ankara: MoNE General Directorate of Assessment and Examination Services.

Ministry of National Education (MoNE), (2018). Mathematics lesson curriculum (Primary and secondary schools 1,2,3,4,5,6,7 and 8th grades), Ankara.

Napitupulu, B. (2001). An exploration of students' understanding and Van Hieles of thinking on geometric constructions (Unpublished master's thesis). Simon Fraser University, Canada.

National Council of Teachers of Mathematics (NCTM), (2000). Principles and standards for school mathematics. Reston, VA: National Council of Teachers of Mathematics.

Olkun, S. (2003). Making connections: Improving spatial abilities with engineering drawing activities. International journal of mathematics teaching and learning, 3(1), 1-10.

Olkun, S., \& Toluk, Z. (2007). İlköğretimde etkinlik temelli matematik öğretimi [Activitybased mathematics teaching in primary education]. Ankara, Turkey: Maya Academy Publication Distribution.

Özdemir, A. Ş., \& Y1ldiz, S. G. (2015). The examination of elementary mathematics preservice teachers' spatial abilities. Procedia - Social and Behavioral Sciences, 174, 594-601. https://doi.org/10.1016/j.sbspro.2015.01.588

Padiotis, I., \& Mikropoulos, T.A. (2010). Using SOLO to evaluate an educational virtual environment in a technology education setting. Educational Technology \& Society, $13(3), 233-245$.

Pegg, J. \& Tall, D. (2001). Fundamental cycles in learning algebra: An analysis. 10 October 2020 , http://www.warwick.ac.uk/staff/David.Tall/drafts/dot2001z-pegg-icmialgebra.pdf

Pegg, J., \& Davey, G. (1998). Interpreting Student Understanding in Geometry: A Synthesis of Models (s.109-135). Ed: Richard Lehrer ve Daniel Chazen, In Designing Learning Environments for Developing Understanding of Geometry and Space., NJ: Lawrence Erlbaum Associates, Mahwah.

Pittalis, M., Christou, C., \& Papageorgiou, E. (2003). Students' ability in solving proportional problems. Proceedings of the 3rd European Research Conference in Mathematics Education: Bellaria: Italy, 3.

Şengün, K.Ç. (2017). Investigation of secondary school students construction process of triangle in paper-pencil and dynamic geometry environment. (Unpublished master's thesis). Pamukkale University, Denizli.

Shulman, L. S. (1986). Those who understand: Knowledge growth in teaching. Educational Researcher, 15(2), 4-14. https://doi.org/10.3102/0013189X015002004

Strauss, A. L., \& Corbin, J. M. (1998). Basics of qualitative research: Techniques and procedures for developing grounded theory $\left(2^{\text {nd }}\right.$ ed $)$. Sage Publications.

Tekin, A. T. (2007). Comparative investigation of nineth and eleventh grade students mental rotation and spatial visualization abilities. (Unpublished master's thesis). Ankara University, Ankara.

Tomperi, P. (2016). SOLO taxonomy supporting practical chemistry instruction. LUMAT-B: International Journal on Math, Science and Technology Education, 1(3). Retrieved from https://journals.helsinki.fi/lumatb/article/view/1202

Türnüklü, A. (2000). Qualitative research technique that can be used effectively in pedagogical research: Interview. Educational Administration: Theory and Practice, 6(4), 543-559. 
Turkey Republic Health Ministry (TRHM), (2020). https://covid19.saglik.gov.tr/TR66470/fiziki-mesafe--sosyal-mesafe.html 25 Ocak 2021.

Usiskin, Z. (1982). Van Hiele levels and achievement in secondary school geometry. Final report of the Cognitive Development and achievement in secondary school geometry project, University of Chicago, Department of Education.

Van Dooren, W., Verschaffel, L., \& Onghena, P. (2002). The impact of preservice teachers' content knowledge on their evaluation of students' strategies for solving arithmetic and algebra word problems. Journal for Research in Mathematics Education, 33(5), 319-351. JSTOR. https://doi.org/10.2307/4149957

Van Hiele, P. (1986). Structure and insight: A theory of mathematics education. London: Academic Press.

Weyers, M. (2006). Teaching the FE Curriculum: Encouraging active learning in the classroom. London: Continuum.

Yi, M., Flores, R., \& Wang, J. (2020). Examining the influence of van Hiele theory-based instructional activities on elementary preservice teachers' geometry knowledge for teaching 2-D shapes. Teaching and Teacher Education, 91, 103038. https://doi.org/10.1016/j.tate.2020.103038

Yı1dırım, A., \& Şimşek, H. (2016). Sosyal bilimlerde nitel araştırma yöntemleri. [Qualitative research methods in the social sciences]. Ankara: Seçkin Publications.

Y1lmaz, G. K., \& Koparan, T. (2015). The effect of designed geometry teaching lesson to the candidate teachers' Van Hiele geometric thinking level. Journal of Education and Training Studies, 4(1), 129-141. https://doi.org/10.11114/jets.v4i1.1067

Yin, R. K. (1984). Case study research: Design and methods. Beverly Hills, Calif: Sage Publications. 